\title{
The Role of Leader-Member Exchange in Moderating the Influence of Competence, Innovative Behavior, and Career Development on Employee Engagement
}

\author{
Uce Veriyanti and Mafizatun Nurhayati
}

\section{ABSTRACT}

\begin{abstract}
This research investigated the influence of competence, innovative behavior, and career development on employee engagement through the leadermember exchange as moderating variable. This research was conducted in the Ministry of Education, Culture, Research, and Technology of the Republic of Indonesia. The study targeted Civil Service Employees within the circle of Direktorat Sekolah Menengah Atas (High Schools Directorate) in the Ministry of Education, Culture, Research and Technology of the Republic of Indonesia. The research design used quantitative causal research. Primary data collection was conducted through a survey with a questionnaire instrument distributed to 114 respondents. The data analysis method used the structural equation model-partial least square (SEM-PLS). Results indicated that competence, innovative behavior, and career development showed positive and significant influence on employee engagement. In addition, leader-member exchange also showed a significant effect as moderating variable in building the influence of competence, innovative behavior, and career development on employee engagement.
\end{abstract}

Keywords: Competence, career development, employee engagement, innovative behavior, leader member exchange.

\section{INTRODUCTION}

Employee engagement is defined as involvement, enthusiasm, and commitment to work and the workplace. Employee engagement also means a person's attachment and attitude to their organization, where their work and performance are acknowledged and reflected by the individual themselves in an organization (Saks, 2006). Several studies on employee engagement conducted by TinyPulse, Kincentric, a human capital and talent management consultant, in 2020 stated that most companies had not implemented employee engagement optimally. It is proven in the report "The 2019 Employee Engagement Report" issued by TinyPulse that one of the things that had decreased was employee loyalty. Based on the report, about $43 \%$ of employees wanted to leave the company for a $10 \%$ salary increase at another company. This was due to the lack of involvement of the company and weak corporate culture. On the other hand, Gallup's research in (Ratanje \& Emond, 2013) on employee engagement paints a grim picture. Only $8 \%$ of Indonesian employees were engaged at work, while $15 \%$ were inactive.

It is imperative that organization experiences the true essence of work engagement, especially in the public sector, to identify its drivers better (Khusanova et al., 2021). Likewise, the Ministry of Education, Culture, Research, and Technology, regards public officials as one of the main assets in promoting public sector reformation. However, although research on employee engagement is growing, there are few studies on employee engagement in public organizations (Khusanova et al., 2021). Given that uninvolved employees are costly for public organizations, it is essential to identify the drivers of labor participation in the sector.

Research (Nazir, 2019) showed that awareness of work goals positively affected employee performance. On the other side, employee experience had little effect on performance. It was also found that employee engagement positively impacted performance. Based on this research, CSR programs can provide awareness of goals and meaning to increase employee engagement and performance in their workplace. Other research on the factors that influence employee engagement according to (Agustian et al., 2018) is the competence of employee and commitment to performance. According to (Wirjadi, 2014), (Haddud et al., 2016), and (Maus, 2018) stated, several factors that influence employee engagement are innovative behavior, effectiveness of performance management, employee performance, and leader-member exchange.

In line with above phenomenon, this article examines the role of leader-member exchange in moderating the influence of competence, innovative behavior, and career development on employee engagement within the Ministry of Education, Culture, Research, and Technology, especially at the High Schools Directorate during Covid-19 pandemic, which requires most employees to work from home. 


\section{LITERATURE REVIEW}

\section{A. Competence and Employee Engagement}

Competence is a characteristic that is inherently possessed by an individual to complete their job properly; this is represented by knowledge, proficiency, and expertise (Wirotomo \& Pasaribu, 2015). Competence can be improved and influenced to boost employee engagement in the company. Employee engagement is a psychological aspect that exists within an employee while working and performing their role in the organization. In performing their role, employees with engagement will eagerly work using their emotions, cognitive, and physics (Sun \& Bunchapattanasakda, 2019). Competence-based employees can improve work performance (Paluta \& Widjojo, 2018). If employees in an organization work according to their competencies, the tasks will be completed properly and produce good outputs. When an employee works aligned to their competencies, then his engagement towards their job will greatly rise.

H1: Competence has a positive effect on employee engagement.

\section{B. Innovative Behaviour and Employee Engagement}

Innovative behavior aims to promote, create, and implement new ideas, processes, products, and procedures in job roles, organizations, or groups to benefit the performance of each role, organization, and the group itself (Dewi \& Dewi, 2018). Twiss in (Kogabayev \& Maziliauskas, 2017) defined innovation as a process that combines science, technology, economics, and management to achieve novelty and improvement by generating ideas to commercialize through production, exchange, and consumption. In addition, innovative behavior encourages employees to do their tasks with emotions, cognitive, and physics. This shows that innovative behavior can improve employee engagement (Joushan et al., 2015).

$\mathrm{H} 2$ : Innovative behavior has a positive effect on employee engagement.

\section{Career Development and Employee Engagement}

A career is an entire job position handled during the working life of an individual (Handoko \& Hani, 2000). Career development is basically oriented towards organizational/company development responding to future business challenges. Every organization/company should realize that their future depends on human resources (Nawawi, 2016). Without competitive human resources, an organization will experience setbacks and eventually be excluded due to the inability to confront their competitors. Such conditions require the organization/company to conduct career development for employees that must be planned and sustained. In addition, good career development can encourage and increase employee engagement (Hanifah et al., 2020).

H3: Career development has a positive effect on employee engagement.

D. Competence, Innovative Behaviour, Career Development and Employee Engagement with Leader Member Exchange (LMX)Interaction

Leader-member exchange (LMX) is a reciprocal relationship between superiors and subordinates, which is indicated by desired behavior, improved communication, feedback on optimal performance, and good working relationships (Latief \& Ika, 2016). Northouse in (Latief \& Ika, 2016) states that LMX as a vertical exchange is more focused on exchanging leaders with members, where subordinates receive more influence, information, roles, and trust from leaders in the same work unit than from outside the group. On the other hand, unit leaders work the same way for their company, while members act more for their leaders. According to (Maus, 2018), as the LMX quality grew higher between the leader and the employee, employee engagement would rise. Additional effects on employee engagement levels are related to employee gender and their educational level.

A good reciprocal relationship between superiors and subordinates will encourage more decisive influence of competence in increasing employee engagement (Breevart $e t$ al., 2015). Leader-member exchange plays a role in moderating the effect of innovative behavior on employee engagement (Kananu \& Ambrose, 2020). A reciprocal relationship between leaders and employees will undoubtedly allow employees to communicate and discuss with leaders and vice versa, to express creative ideas and strengthen innovative behavior so that employee engagement will increase. Likewise, LMX will enhance the influence of innovative behavior on employee engagement. A good reciprocal relationship between superiors and subordinates will impact leaders to better understand the work of their subordinates and determine the career needs of their subordinates; thus, career development will further strengthen its influence on employee engagement (Robin et al., 2018).

H4: Leader-member exchange has a positive effect on employee engagement.

H5: Leader-member exchange plays a role in moderating the influence of competence on employee engagement

H6: Leader-member exchange plays a role in moderating the influence of innovative behavior on employee engagement.

H7: Leader-member exchange plays a role in moderating the influence of career development on employee engagement.

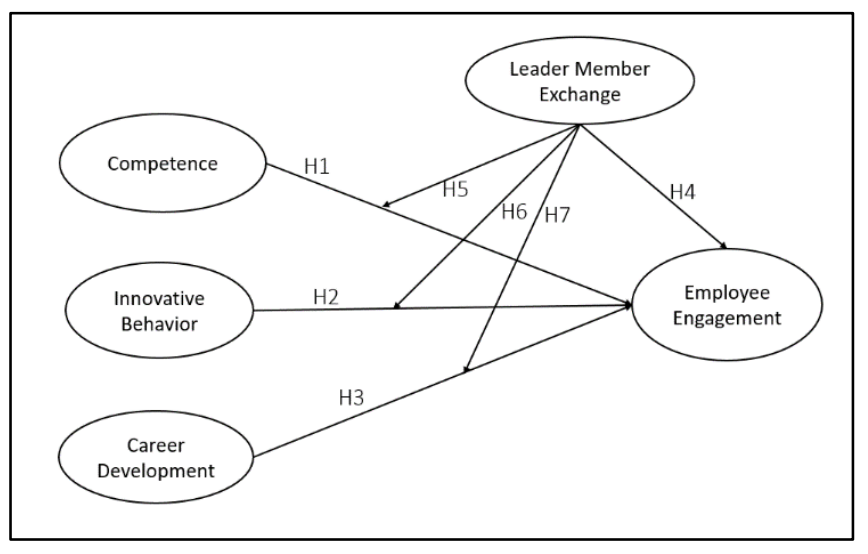

Fig. 1. Conseptual Model. 


\section{ReSEARCH Methodology}

\section{A. Variable Measurement}

According to (Schaufeli \& Bakker, 2004) the dimensions of employee engagement as variable consist of vigor, dedication, and absorption. The dimension used to measure the quality level of leader-member exchange is comprised of respect, trust, and the respect for profession, according to (Graen \& Uhl-Bien, 1995). In (Edison et al., 2016) the dimensions of competence are knowledge, understanding, skill, value, and attitude. The dimensions to measure the level of innovative behavior according to Robbins \& Coulter in (Tewal et al., 2017) are consisted of innovation, risk taking behavior, attention, result oriented, people oriented, and aggressivity. Based on (Sihotang, 2007), career development's dimensions are organizational policy, work achievement, education, training, and work experience.

\section{B. Population and Sample}

The population of this research are Civil Service Employee of Ministry of Education, Culture, Research, and Technology particularly within Direktorat Sekolah Menengah Atas (High Schools Directorate). The samples consist of 114 employees while using total population sampling method. The characteristics of respondents are divided into age, sex, position, education, and working period.

Most respondents are male $(57,02 \%)$. According to age, most respondents are seniors with abundant work experiences within the age range of $41-50$ years old $(41,23 \%)$ and working period of $11-15$ years $(36,84 \%)$. Employees in this age range tend to be more stable when working due to a relatively long working period, yet they may feel dispassionate over the routines. Most respondents have a bachelor's degree of education $(42,98 \%)$, while some have a high school degree $(33,33 \%)$. However, this level of education does not determine the work performance of employees. About 95 respondents $(83,34 \%)$ have job position as staff, while 17 respondents as functional officers $(14,91 \%)$, and 2 respondents as structural officers $(1,75 \%)$. Structural officials consist of only 2 persons since the annulment of echelon III and IV officials in 2020.

\section{Data Analysis}

This study uses the Structural Equation Model-Partial Least Square (SEM-PLS) analysis method and the Smart-PLS as analysis tool. SEM-PLS has the advantage to be applied for fewer number of samples with no assumption in data distribution.

\section{RESEARCH RESUlt}

Descriptive research variables are used to determine the response bias in the questionnaire according to the category of answer using Likert scale within the range of 1 (Strongly Disagree) to 5 (Strongly Agree) on the statements of each variable. Then, the accumulated data was tabulated and calculated to determine the average score and the distribution of responses from each item in the variables. The average score data of descriptive variables can be seen in Table I.
TABLE I: CONVERGENT VALIDITY TEST WITH LOADING FACTOR AND VARIABLE DESCRIPTIVE SCORE

\begin{tabular}{|c|c|c|c|c|c|}
\hline Variable & Dimensions & Items & Mean & $\begin{array}{c}\text { Loading } \\
\text { Factor }\end{array}$ & $\begin{array}{c}\text { Descriptive } \\
\text { Variable } \\
\text { Average } \\
\text { Score }\end{array}$ \\
\hline \multirow{16}{*}{ Competence } & \multirow{3}{*}{ Knowledge } & $\mathrm{X} 1.1$ & 3,816 & 0,895 & \multirow{16}{*}{3,72} \\
\hline & & $\mathrm{X} 1.2$ & 3,746 & 0,837 & \\
\hline & & $\mathrm{X} 1.3$ & 3,789 & 0,883 & \\
\hline & \multirow{3}{*}{ Understanding } & $\mathrm{X} 1.4$ & 3,789 & 0,762 & \\
\hline & & $\mathrm{X} 1.5$ & 3,658 & 0,901 & \\
\hline & & $\mathrm{X} 1.6$ & 3,702 & 0,882 & \\
\hline & \multirow{4}{*}{ Skills } & $\mathrm{X} 1.7$ & 3,614 & 0,815 & \\
\hline & & $\mathrm{X} 1.8$ & 3,737 & 0,863 & \\
\hline & & X1.9 & 3,667 & 0,776 & \\
\hline & & $\mathrm{X} 1.10$ & 3,693 & 0,869 & \\
\hline & \multirow{3}{*}{ Value } & $\mathrm{X} 1.11$ & 3,772 & 0,857 & \\
\hline & & $\mathrm{X} 1.12$ & 3,719 & 0,842 & \\
\hline & & $\mathrm{X} 1.13$ & 3,667 & 0,796 & \\
\hline & \multirow{3}{*}{ Attitude } & $\mathrm{X} 1.14$ & 3,658 & 0,841 & \\
\hline & & $\mathrm{X} 1.15$ & 3,763 & 0,831 & \\
\hline & & $\mathrm{X} 1.16$ & 3,693 & 0,826 & \\
\hline \multirow{12}{*}{$\begin{array}{c}\text { Innovative } \\
\text { Behavior }\end{array}$} & \multirow{3}{*}{$\begin{array}{c}\text { Innovation } \\
\text { and risk- } \\
\text { taking }\end{array}$} & $\mathrm{X} 2.1$ & 3,860 & 0,906 & \multirow{12}{*}{3,89} \\
\hline & & $\mathrm{X} 2.2$ & 3,912 & 0,927 & \\
\hline & & $\mathrm{X} 2.3$ & 3,816 & 0,908 & \\
\hline & & $\mathrm{X} 2.4$ & 3,930 & 0,909 & \\
\hline & Attention & $\mathrm{X} 2.5$ & 4,009 & 0,885 & \\
\hline & & $\mathrm{X} 2.6$ & 3,947 & 0,839 & \\
\hline & Result & $\mathrm{X} 2.7$ & 3,754 & 0,766 & \\
\hline & orientation & $\mathrm{X} 2.8$ & 3,921 & 0,894 & \\
\hline & People & X2.9 & 3,868 & 0,893 & \\
\hline & orientation & $\mathrm{X} 2.10$ & 3,851 & 0,870 & \\
\hline & \multirow{2}{*}{ Aggression } & $\mathrm{X} 2.11$ & 3,912 & 0,837 & \\
\hline & & $\mathrm{X} 2.12$ & 3,921 & 0,852 & \\
\hline \multirow{15}{*}{$\begin{array}{c}\text { Career } \\
\text { Development }\end{array}$} & \multirow{3}{*}{$\begin{array}{l}\text { Organization } \\
\text { policy }\end{array}$} & $\mathrm{X} 3.1$ & 3,474 & 0,760 & \multirow{15}{*}{3,27} \\
\hline & & $\mathrm{X} 3.2$ & 3,500 & 0,849 & \\
\hline & & $\mathrm{X} 3.3$ & 3,491 & 0,830 & \\
\hline & \multirow{3}{*}{$\begin{array}{c}\text { Work } \\
\text { achievement }\end{array}$} & X3.4 & 3,395 & 0,850 & \\
\hline & & $\mathrm{X} 3.5$ & 3,456 & 0,792 & \\
\hline & & $\mathrm{X} 3.6$ & 3,412 & 0,791 & \\
\hline & & X3.7 & 3,404 & 0,828 & \\
\hline & Educational & $\mathrm{X} 3.8$ & 3,184 & 0,849 & \\
\hline & & X3.9 & 3,184 & 0,830 & \\
\hline & & X3.10 & 3,167 & 0,719 & \\
\hline & Training & X3.11 & 3,035 & 0,728 & \\
\hline & & $\mathrm{X} 3.12$ & 2,965 & 0,801 & \\
\hline & & X3.13 & 3,158 & 0,760 & \\
\hline & $\begin{array}{l}\text { Work } \\
\text { experience }\end{array}$ & X3.14 & 3,158 & 0,825 & \\
\hline & & $\mathrm{X} 3.15$ & 3,088 & 0,746 & \\
\hline & & $\mathrm{X} 4.1$ & 3,377 & 0,825 & \\
\hline & Respect & $\mathrm{X} 4.2$ & 3,289 & 0,767 & \\
\hline & & $\mathrm{X} 4.3$ & 3,711 & 0,909 & \\
\hline Leader- & Trust & $\mathrm{X} 4.4$ & 3,658 & 0,899 & \\
\hline Member & & $\mathrm{X} 4.5$ & 3,640 & 0,871 & 3,57 \\
\hline Exchange & & $\mathrm{X} 4.6$ & 3,561 & 0,904 & \\
\hline & Respect for & $\mathrm{X} 4.7$ & 3,623 & 0,892 & \\
\hline & the profession & $\mathrm{X} 4.8$ & 3,711 & 0,909 & \\
\hline & & $\mathrm{X} 4.9$ & 3,570 & 0,903 & \\
\hline & & Y1.1 & 3,684 & 0,899 & \\
\hline & Spirit & $\mathrm{Y} 1.2$ & 3,711 & 0,885 & \\
\hline & & Y1.3 & 3,693 & 0,874 & \\
\hline & & Y1.4 & 3,561 & 0,906 & \\
\hline Employee & Dedication & Y1.5 & 3,561 & 0,902 & 3,64 \\
\hline Engagement & & Y1.6 & 3,702 & 0,900 & \\
\hline & & Y1.7 & 3,544 & 0,914 & \\
\hline & Absorption & Y1.8 & 3,632 & 0,890 & \\
\hline & & Y1.9 & 3,711 & 0,914 & \\
\hline
\end{tabular}

\section{A. Evaluation of the Reflective Measurement Model (Outer Model)}

This study uses the Structural Equation Model-Partial Least Square (SEM-PLS) analysis method and the Smart-PLS as analysis tool. SEM-PLS has the advantage to be applied for fewer number of samples with no assumption in data 
distribution.

Table I shows that most of the respondents gave favorable responses to questions related to competence, innovative behavior, leader-member exchange, and employee engagement. It is represented by the average score of the assessment above 3.50. In addition, the career development variable had an average score of 3.27 , which indicates that respondents had given adequate responses to the questions. Table I also shows that all indicators produce a loading factor value above 0.7 , which implies that all indicators are qualified to measure the dimensions as it will have a higher contribution to define the latent construct.

Table II shows the results of concurrent validity testing with Average Variance Extracted (AVE), discriminant validity, and reliability tests. In testing the convergent validity, the limit of the AVE value used is 0.5. Therefore, based on the validity test results, all variables produce an AVE value greater than 0.5 ; thus, it can be stated that all research variables are valid.

In Table II, each variable has a good discriminant validity value based on the Fornell-Larcker Criterion. The root AVE value for each construct is greater than the correlation value to the other constructs in the model. The HeterotraitMonotrait Ratio (HTMT) results also suggests that each variable has a good discriminant validity value since the ratio value is smaller than 0.85 . Even though the value of the employee engagement ratio to the leader-member exchange is greater than 0.85 , it can be stated as having a good convergent validity value as the ratio value is not more than 0.90. In Table II, all research variables have composite reliability and Cronbach's alpha values greater than 0.7 . Thus, it can be concluded that the construct has a good discriminant validity value, which is reliable and consistent as a measuring tool to be applied in this study.

\section{B. Evaluation of Structural Measurement Model (Inner Model)}

Structural model testing is seen based on the significance of relationship between constructs or variables (Haryono \& Parwoto, 2017). The path coefficient describes the strength of relationships between constructs. The structural model test was conducted to assess the coefficient of determination (R2), Effect Size (f2), Predictive Relevance Value (Q2), and Tstatistics.
Based on Table III, the coefficient of determination $\left(\mathrm{R}^{2}\right)$ is 0.924 . It shows that the competence can define the diversity of employee engagement, innovative behavior, and career development variables by $92.4 \%$. In comparison, the remaining $7.6 \%$ is a contribution from other variables that will not be discussed in this study. Thus, the formed structural model is well-founded.

TABLE III: INNER MODEL: R SQUARE, EFFECT SIZE, Q², GoF

\begin{tabular}{ccccc}
\hline & R Square & $\begin{array}{c}\text { Effect Size } \\
\left(\mathrm{f}^{2}\right)\end{array}$ & Q Square & GoF \\
\hline C & & 0,619 & & \\
IB & & 1,141 & & \\
CD & 0,924 & 0,284 & 0,815 & 0,826 \\
LMX & & 0,148 & & \\
EE & & - & & \\
\hline
\end{tabular}

The $\mathrm{f} 2$ values of $0.02,0.15$, and 0.35 are interpreted as respectively having small, moderate, and large effect of latent variable predictors on the structural level according to Chin in (Ghozali \& Hengky, 2015). Based on the test results, the variables of competence, innovative behavior of employees, and career development have a large influence on employee engagement and is indicated by the $\mathrm{f} 2$ value that is greater than 0.15 . While the leader-member exchange variable has a moderate influence on employee engagement and is indicated by the $\mathrm{f} 2$ value of 0.148 .

The test of predictive relevance $(\mathrm{Q} 2)$ has a function to validate the model. Predictive relevance $(\mathrm{Q} 2)$ results are said to be good if the value is greater than zero. Based on the results of the redundancy test of construct cross-validation presented in Table III, the formed structural model has a wellfounded predictive relevance as the value of Q2 is greater than zero. This implies that exogenous latent variables can predict employee engagement as explanatory variables.

Goodness of Fit (GoF) is used to validate the overall model, GoF index is a single measure used to validate the combined performance of the measurement model (outer model) and structural model (inner model). According to (Edalmen, 2020), the GoF value ranges from $0-1$ with the interpretation of values divided into three, namely 0.1 (small), 0.25 (medium), and 0.38 (large). Based on the calculation results, the GoF value obtained is 0.826 ; thus, the model has a high proficiency in defining empirical data. Overall, it can be concluded that the formed model is valid.

TABLE II: CONVERGENT VALIDITY, DISCRIMINANT VALIDITY AND CONSTRUCT RELIABILITY

\begin{tabular}{|c|c|c|c|c|c|c|c|c|c|c|c|c|}
\hline \multirow[b]{2}{*}{ Variables } & \multirow[b]{2}{*}{ AVE } & \multicolumn{5}{|c|}{ Fornell-Larcker Criterion } & \multicolumn{5}{|c|}{ Heterotrait-Monotrait Ratio (HTMT) } & Reliability \\
\hline & & $\mathrm{C}$ & IB & $\mathrm{CD}$ & LMX & $\mathrm{EE}$ & $\mathrm{C}$ & IB & $\mathrm{CD}$ & LMX & $\mathrm{EE}$ & $\begin{array}{c}\text { Cronbach's } \\
\text { Alpha }\end{array}$ \\
\hline Competence $(\mathrm{C})$ & 0,711 & 0,948 & & & & & & & & & & 0,973 \\
\hline Innovative Behavior (IB) & 0,765 & 0,301 & 0,933 & & & & 0,305 & & & & & 0,972 \\
\hline Career Development (CD) & 0,638 & 0,520 & 0,535 & 0,885 & & & 0,513 & 0,548 & & & & 0,960 \\
\hline Leader-Member Exchange (LMX) & 0,768 & 0,451 & 0,573 & 0,762 & 0,932 & & 0,468 & 0,605 & 0,815 & & & 0,962 \\
\hline Employee Engagement (EE) & 0,807 & 0,594 & 0,683 & 0,787 & 0,847 & 0,975 & 0,607 & 0,703 & 0,799 & 0,885 & & 0,970 \\
\hline \multicolumn{13}{|c|}{ TABLE IV: HYPOTHESIS TESTING RESULTS } \\
\hline \multicolumn{6}{|c|}{ Variable } & \multicolumn{2}{|c|}{ Coefficient } & \multicolumn{2}{|c|}{ T-statistics } & \multicolumn{2}{|c|}{ P-Values } & Description \\
\hline \multicolumn{6}{|c|}{ Competence $\rightarrow$ Employee Engagement } & \multicolumn{2}{|c|}{0,162} & \multicolumn{2}{|c|}{4,296} & \multicolumn{2}{|c|}{0,000} & H1 Accepted \\
\hline \multicolumn{6}{|c|}{ Innovative Behavior $\rightarrow$ Employee Engagement } & \multicolumn{2}{|c|}{0,531} & \multicolumn{2}{|c|}{7,722} & \multicolumn{2}{|c|}{0,000} & $\mathrm{H} 2$ Accepted \\
\hline \multicolumn{6}{|c|}{ Career Developement $\rightarrow$ Employee Engagement } & \multicolumn{2}{|c|}{0,247} & \multicolumn{2}{|c|}{5,198} & \multicolumn{2}{|c|}{0,000} & H3 Accepted \\
\hline \multirow{2}{*}{\multicolumn{6}{|c|}{ Leader-Member Exchange $\rightarrow$ Employee Engagement }} & \multicolumn{2}{|c|}{0,207} & \multicolumn{2}{|c|}{2,767} & \multicolumn{2}{|c|}{0,006} & H4 Accepted \\
\hline & & & \multicolumn{3}{|c|}{ KOMxLMX $\rightarrow$ Employee Engagement } & \multicolumn{2}{|c|}{0,072} & \multicolumn{2}{|c|}{2,419} & \multicolumn{2}{|c|}{0,016} & H5 Accepted \\
\hline \multicolumn{6}{|c|}{ PIPxLMX $\rightarrow$ Employee Engagement } & \multicolumn{2}{|c|}{0,328} & \multicolumn{2}{|c|}{8,170} & \multicolumn{2}{|c|}{0,000} & H6 Accepted \\
\hline PKxLM & $\rightarrow \mathrm{Emp}$ & oyee En & zagemen & & & 0,36 & & 9,1 & & 0,0 & & H7 Accepted \\
\hline
\end{tabular}


Based on Table IV, all independent variables including moderating variables have a significant influence on employee engagement at $5 \%$. It is indicated by a smaller $\mathrm{p}$ value of 0.05 . The structural model result is as follows:

\section{Employee engagement $=0,162 \mathrm{X} 1+0,531 \mathrm{X} 2+0,247 \mathrm{X} 3$ $+0,207 \mathrm{X} 4+0,072 \mathrm{KOMxLMX}+0,328 \mathrm{PIPxLMX}+$ $0,361 \mathrm{PKXLMX}$}

\section{DISCUSSION}

\section{A. The Effect of Competence on Employee Engagement}

Based on the testing of the hypothesis model, competence affects employee engagement, which is indicated by a significance value that is smaller than the required level. The acquired result shows a positive coefficient value for variables. This means that if competence is improved, there will be an increase in employee engagement. Based on the loading factor coefficient, employee understanding has a dominant role on competence in influencing employee engagement variables. Therefore, employee understanding is an important part of competence to improve employee engagement at the High Schools Directorate.

The relationship between the two variables was strengthened by several studies. In (Paluta \& Widjojo, 2018), it was stated that competency-based human resources could affect employee engagement in improving an organization's performance and achievement as competent employees have great involvement and have good work output.

\section{B. The Effect of Innovative Behavior on Employee Engagement}

The testing results of the structural hypothesis model show that innovative behavior has a significant and positive effect on employee engagement. It means that changes in the value of innovative behavior are in line with changes in employee engagement. In other words, if innovative behavior improves, there will be an increasing level of Employee Engagement. Based on the loading factor coefficient, employees' innovative behavior is dominated by innovation, risk-taking behavior, and attention. High Schools directorate employees are likely to try developing new ideas and be thorough in carrying out their work. Result orientation is the least in influencing innovative behavior. It implies that employees of the High Schools Directorate tend to pay attention to inputs (ideas/ideas) and processes in their work compared to results. This is aligned with previous research, particularly (Joushan et al., 2015). It was stated that organizational culture and innovative behavior significantly affected employee engagement. An employee who has innovative behavior will constantly be involved in making contribution towards his organization as he is trying to express his ideas for the advancement of his organization.

\section{The Effect of Career Development on Employee Engagement}

Career development has a positive and significant effect on employee engagement. This implies that if career development improves, there will be an increasing level of employee engagement. Based on loading factor test results, work performance has a dominant influence on the career development of High Schools Directorate employees. It suggests that the career path of High Schools Directorate employees is likely to be determined based on the employee's work performance. The relationship between career development variables and employee engagement was strengthened by research (Hanifah et al., 2020), which stated that career development significantly affected employee work engagement. The study explained that when an employee achieved progress in his career, the employee would be more motivated in being involved and vocal, seeing that there would be further career development.

\section{The Effect of Leader-Member Exchange on Employee Engagement}

Leader-member exchange (LMX) has a positive and significant influence on employee engagement. Changes in LMX values have unidirectional effects on changes in employee engagement, which means that if LMX improves, employee engagement will also increase. LMX is strongly influenced by respect for the profession. In general, leaders and employees of the High Schools Directorate have good relationships; thus, creating trust towards the leader. The relationship between LMX variables and employee engagement was in line with previous research (Maus, 2018) which suggested that the quality of LMX significantly affected employee engagement. The higher the LMX quality between the leader and the employee, the greater will the employee be engaged.

\section{E. The Role of Leader-Member Exchange in Moderating the Effect of Competence on Employee Engagement}

Leader-member exchange (LMX) has a significant role in changing the influence of competence on employee engagement. LMX is to strengthen the influence of competence on employee engagement. It means that if LMX changes, there will be changes in the influence level of competence on employee engagement. This moderating variable is fictitious since apart from being able to moderate the competency variable, the LMX variable also directly influences employee engagement. The relationship between these variables was aligned with previous research (Kurniasari \& Armanu, 2018). It was found that competence indirectly affected employee engagement. Furthermore, (Breevart et al., 2015) conducted a study on the effect of leader-member exchange and competence on employee engagement. As a result, leader-member exchange played a role in moderating the effect of competence on employee engagement. When the leader-member exchange can be implemented properly, improvement in the competence will increase the involvement of employees.

\section{F. The Role of Leader-Member Exchange in Moderating the Effect of Innovative Behavior on Employee Engagement}

Leader-member exchange (LMX) has a significant role in changing the influence of innovative behavior on employee engagement. This implies that if the leader-member exchange changes, there will be changes in the influence level of innovative behavior on employee engagement. This moderating variable is fictitious and strengthens the relationship between innovative behavior and employee engagement, which is indicated by a positive path coefficient value. Good relations between leaders and employees at the 
High Schools Directorate can encourage employees to display innovative behavior and create a high sense of enthusiasm and dedication while working. It was supported by research conducted by (Pitoyo \& Sawitri, 2016) and research (Kananu \& Ambrose, 2020) which stated that leadermember exchange significantly moderated innovative behavior.

\section{G. The Role of Leader-Member Exchange in Moderating the Effect of Career Development on Employee Engagement}

Leader-member exchange (LMX) has a significant role in changing the influence of career development on employee engagement. If the Leader-member exchange changes, there will be changes in the influence level of career development on employee engagement. This moderating variable is fictitious and strengthens the influence of career development on employee engagement. It is indicated by the path coefficient value which is positive and each of these coefficients has a significant value. The relationship between these variables was in line with previous research (Dharma et al., 2021) which stated that the existence of a leader-member exchange in transformational leadership could significantly moderate the effect of employee career development at PT. Denpasar Space Gate. Furthermore, (Hanifah et al., 2020) in his research explained that when an employee achieved career development, the employee would be more motivated in being involved and vocal, seeing that there would be further career development.

\section{CONCLUSION AND SUGGESTION}

Based on results and discussions of the research, it can be concluded that competence has a positive effect on employee engagement. Innovative behavior has a positive effect on employee engagement. Career development has a positive effect on employee engagement. Leader-member exchange has a positive effect on employee engagement. Leader member exchange can moderate the influence of competence on employee engagement. Leader-member exchange can moderate the influence of innovative behavior on employee engagement. Leader-member exchange can moderate the influence of career development on employee engagement.

Suggestions for improvement from this research, institutions need to hold training activities and regular meetings to broaden employees' understanding of their work. Furthermore, it is necessary to hold weekly evaluation meetings to see the progress of outputs and provide opportunities for employees in the environment of High Schools Directorate. This imperative as a forum to express their opinions/ideas and to resolve problems in job constraints. It is essential to give awards to employees with good performance achievements. The leaders should provide accessible communication for all employees as well as the means of expressing challenges and problems regardless of position and status of each employee.

The limitation of this research was in using electronic form as instruments. Hence all respondents could have different perceptions of the provided statement. Future research should explore other variables such as leadership, work environment, compensation, and other variables that could promote influence on employee engagement and are yet to be studied. Future research could also be carried out in privately-owned organizations or State-Owned Enterprises (BUMN) to obtain a diverse and broader perspective. Research could be done by direct interview to ensure respondents understand the meaning of each research statements.

\section{REFERENCES}

Agustian, F. A., Poernomo, D., \& Puspitaningtyas, Z. (2018). Pengaruh Kompetensi Dan Komitmen Organisasi Terhadap Kinerja Pegawai. Majalah Ilmiah DIAN ILMU, I7(2). https://doi.org/10.37849/midi.v17i2.83. Indonesian.

Breevaart, K., Demerouti, E. \& Heuvel, M. (2015). Leader-member exchange, work engagement, and job performance. Journal of Managerial Psychology. 30(7), 754-770.

Dewi, D. K.., \& Dewi S. (2018) Perilaku Kerja Inovatif pada Karyawan Industri Pariwisata Ditinjau dari Resiliensi. Insan Jurnal Psikologi dan Kesehatan Mental. 3(2), 83-91. Indonesian.

Dharma, I. K. T., I Wayan S., Ni Nyoman A. N. (2021). Pengaruh Pengembangan Karier terhadap Kinerja Karyawan dengan Kepemimpinan Transformasional sebagai Variabel Moderasi pada PT.Gapura Angkasa Denpasar. Jurnal EMAS. 2(2), 235-243. Indonesian.

Edalmen, P.F.N. (2020) Efek Mediasi Keterikatan Karyawan pada Pengaruh Keadilan Distributif dan Prosedural Terhadap Keinginan Berpindah. Jurnal Ekonomi. 24(3), 400-420. Indonesian.

Edison, E., Anwar, Y., \& Imas, K. (2016). Manajemen Sumber Daya Manusia (Strategi dan Perubahan Dalam Rangka Meningkatkan Kinerja Pegawai dan Organisasi), Cetakan Kesatu, Penerbit: Alfabeta, Bandung. Indonesian.

Ghozali, I., \& Hengky L. (2015) Konsep, Teknik, Aplikasi Menggunakan Smart PLS 3.0 Untuk Penelitian Empiris. Badan Penerbit Universitas Diponegoro, Semarang.

Graen, G. B., \& Uhl-Bien, M. (1995). Relationship-based approach to leadership: Development of leader-member exchange (LMX) theory of leadership over 25 years: Applying a multi-level multi-domain perspective. The Leadership Quarterly, 6(2), 219-247. https://doi.org/10.1016/1048-9843(95)90036-5.

Haddud, A., Dugger, J., \& Gill, P. (2016). Exploring the impact of internal social media usage on employee engagement. Journal of Social Media for Organizations, 3(1), 1 - 23.

Handoko, \& Hani., T. (2000). Manajemen Personalia dan Sumber Daya Manusia. Edisi 2. Penerbit: BPFE, Yogyakarta.

Hanifah, M., Abd, K. D., \& Muhammad, R. B. (2020). Pengaruh Pengembangan Karir, Employee Engagement dan Budaya Organisasi terhadap Kinerja Karyawan (Pada The Bagong Adventure Museum Tubuh Kota Batu), 09(11), 17-21. Indonesian.

Haryono, S., \& Parwoto, W. (2017) Structural Equation Modeling. Penerbit: PT. Intermedia Personalia Utama, Bekasi.

Joushan, S. A., Muhammad S., \& Lindawati, K. (2015) Pengaruh Budaya Organisasi dan Employee Engagement terhadap Kinerja Karyawan pada PT PLN (Persero) Area Bekasi, Jurnal Aplikasi Manajemen, 13(4), 697-703. Indonesian.

Kananu, K.M., \& Ambrose, K. (2020). Employee Empowerment and Innovative Work Behavior: The Moderating Role of Leader Member Exchange. Journal of Management. 3(5), 13-23.

Khusanova, R., Kang, S. W., \& Choi, S. B. (2021). Work Engagement Among Public Employees: Antecedents and Consequences. Frontiers in psychology, 12, 684495. https://doi.org/10.3389/fpsyg.2021.684495. Indonesian.

Kogabayev, T., \& Maziliauskas, A. (2017). The definition and classification of innovation. Holistica Journal. 8(1), 59-72.

Kurniasari, I.C., \& Armanu, T. R. (2018) Peran Komitmen Organisasional dalam Memediasi Pengaruh Kompetensi, Pelatihan dan Budaya Organisasi terhadap Kinerja Perawat. MIX: Jurnal Ilmiah Manajemen, 8(2), 352-371. Indonesian.

Latief, P. M., \& Ika, Z. R. (2016). Leader Member Exchange (LMX) dan Kesejahteraan Psikologis pada Perawat Rawat Inap di RSUD Cideres Majalengka. Jurnal Empati. 5(1), 127-132. Indonesian

Maus, A.L. (2018). Employee Engagement and Leader Member Exchange: A Comparative Study of For-Profit University Staff Members, Dissertation of Doctor Program of Bussiness Administration, School of Advance Studies, University of Phoenix, Arizona, Amerika Serikat.

Nawawi, H., (2016). Manajemen Sumber Daya Manusia. Cetakan Kesembilan. Penerbit: Gadjah Mada University Press, Yogyakarta.

Nazir, A. (2019). Pengaruh Pelatihan dan Disiplin Kerja terhadap Kinerja 
European Journal of Business and Management Research www.ejbmr.org

Karyawan pada PT Surya Mustika. Jurnal Mandiri: Ilmu Pengetahuan, Seni, Dan Teknologi, 3(1), 150-169. https://doi.org/10.33753/mandiri.v3i1.63. Indonesian.

Paluta, S., \& Widjojo, S. (2018) Pengaruh Kompetensi dan Employee Engagement terhadap Kinerja Karyawan di PT. Cahaya Citra Alumindo. Jurnal Agora, 6(1), 1-8. Indonesian.

Pitoyo, D.J., \& Sawitri, H. S. R. (2016) Transformational Leadership, Meaning in Work, Leader Member Exchange (LMX), Job Performance Dan Work Engagement. Jurnal Bisnis dan Manajemen (Journal of Business and Management). 16(2), 15-34.

Ratanjee, V. and Emond, L. (2013). Why Indonesia Must Engage Younger Workers: With half of the country's population under 30, motivating that group will be key to Indonesia's economic success. Busines Journal, December 17, 2013.

Robin, M., Thomas, G., Legood, A., \& Dello, R, S. (2018). Leader-member exchange (LMX) differentiation and work outcomes: Conceptual clarification and critical review. Journal of Organizational Behavior, 39(2), 151-168.

Saks, A.M. (2006) Antecedents and consequences of employee engagement. Journal of Managerial Psychology, 21(7), 600-619.

Schaufeli, W. B., \& Bakker, A. B. (2004). Job demands, job resources, and their relationship with burnout and engagement: A multi-sample study. Journal of Organizational Behavior, 25(3), 293-315. https://doi.org/10.1002/job.248.

Sihotang, A. (2007). Manajemen Sumber Daya Manusia. Penerbit: Pradnya Paramita, Jakarta.

Sun, L., \& Bunchapattanasakda, C. (2019). Employee Engagement: A Literature Review. International Journal of Human Resource Studies. 9. 63. 10.5296/ijhrs.v9i1.14167.

Tewal, B., Adolfina, M. P., \& Hendra N. T. (2017). Perilaku Organisasi. Penerbit: CV. Patra Media Grafindo, Bandung.

Wirjadi, I. (2014). Determinan Keterlibatan Kerja untuk Tercapainya Perilaku. Jurnal Manajemen dan Pemasaran Jasa, 7(1), 23-28. http://dx.doi.org/10.25105/jmpj.v7i1.519. Indonesian.

Wirotomo, D., \& Pasaribu, P. N. (2015). pengaruh Kompetensi, Pengembangan karir, Pendidikan Dan Pelatihan (Diklat) Terhadap Kinerja Pegawai Direktorat Jendral Perimbangan Keuanngan. MIX: Jurnal Ilmiah Manajemen, 5(3), 466-480. Indonesian. 